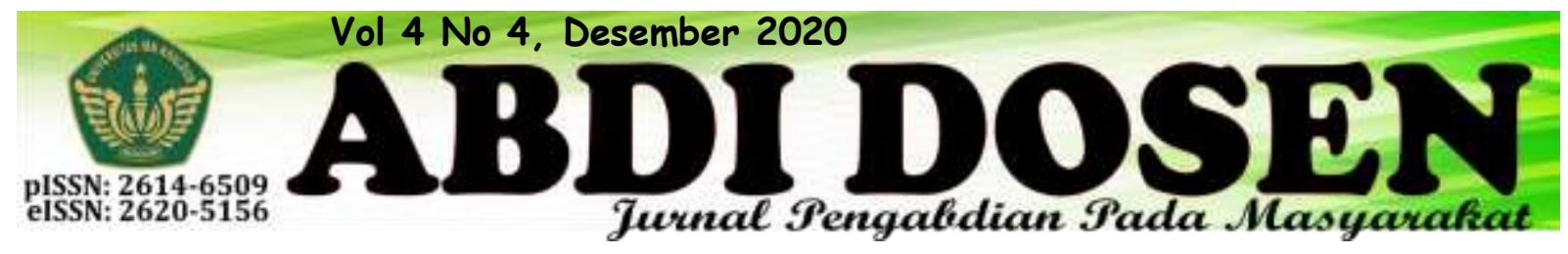

\title{
STRATEGI MEMPERTAHANKAN UMKM SELAMA PANDEMI COVID-19 DI KECAMATAN BUNGKU TENGAH KABUPATEN MOROWALI
}

\author{
Harnida W. Adda ${ }^{1}$, Pricylia Chintya Dewi Buntuang ${ }^{2}$, dan Armawati Sondeng ${ }^{3}$ \\ harnidaadda@gmail.com ${ }^{*}$ \\ pricyliabuntuang@untad.ac.id ${ }^{2}$ \\ armawatison@gmail.com ${ }^{3}$ \\ Jurusan Manajemen Fakultas Ekonomi dan Bisnis \\ Universitas Tadulako, Palu 1,2,3
}

\begin{abstract}
ABSTRAK
Selama pandemi coronavirus disease (COVID-19) bisnis Usaha Mikro Kecil dan Menengah (UMKM) di Indonesia mengalami kelumpuhan. Hal itu disebabkan oleh kebijakan pengendalian COVID-19 yang membuat operasional UMKM menjadi terganggu. Dampaknya, banyak UMKM yang memiliki penurunan pedapatan, bahkan tanpa pendapatan, namun harus membayar pengeluaran rutin seperti gaji, sewa, cicilan dan bunga bank. Kondisi tersebut harus ditanggulangi oleh UMKM agar tetap bertahan. Tujuan dari kegiatan ini adalah untuk memberikan pemahaman dan pengetahuan kepada UMKM dalam mempertahankan usahanya. Adapaun yang menjadi target kegiatan adalah UMKM yang terdampak COVID-19 di Kecamatan Bungku Tengah Kabupaten Morowali. Metode yang digunakan dalam pengabdian ini adalah sosialisasi interaktif dengan pemaparan strategi-strategi untuk mempertahankan UMKM dan melakukan tanya jawab. Strategi perencanaan yang akan disosialisasikan terdiri dari position, plan, perspective, projects, dan preparedness.
\end{abstract}

Keyword: COVID-19, UMKM, Strategi

\section{PENDAHULUAN}

Eksistensi pandemi COVID-19 bukan sekedar mengancam dari aspek kesehatan tapi juga berdampak buruk bagi perekonomian. Pandemi covid-19 yang terjadi belakangan ini merupakan momok bagi setiap individu di negeri ini termasuk para pelaku UMKM sebagai tonggak penyokong perekonomian nasional (Huba, 2020).

Saat ini kita dihadapkan dengan kesiapsiagaan darurat dan respon individu, pemerintah dan bisnis di semua level untuk bertindak cepat mengantisipasi dampak pandemi COVID 19 terhadap ekonomi global, dimulai dengan sektor pariwisata yang terdampak paling awal, dimana banyak perjalanan wisata dibatalkan karena tempat tujuan wisata ditutup pemerintah setempat. Hal ini tentu diikuti oleh sektor transportasi baik darat, laut maupun udara yang mengalami penurunan penumpang sangat signifikan apalagi dengan pemberlakukan Work from Home bagi pegawai di beberapa perusahaan swasta dan pemerintahan. UMKM pun akan terdampak paling berat, karena mereka mengandalkan rantai pasokan yang sekarang hampir terhenti, 
juga penjualan harian yang akan menambah beban pemasukan (Kompasiana.com, 2020).

Situasi ini diperkirakan akan masih berlangsung sepanjang 2020, mulai dari kekurangan pasokan, risiko pengangguran, inflasi, pasar saham yang tidak sesuai harapan, dan penurunan di semua sektor. Langkah praktis untuk mengurangi dampak negatif pada sektor yang paling terkena dampak memerlukan kebijakan korektif di bidang ekonomi dan bisnis serta inovasi yang cepat dan tepat agar dapat menciptakan perilaku baru untuk bertahan.

Usaha Mikro Kecil dan Menengah (UMKM) merupakan sektor perdagangan saat ini dihadapkan pada masalah penurunan penjualan, kesulitan dalam memperoleh bahan baku, produksi dan distribusi yang terhambat, kesulitan modal, kurangnya pengetahuan teknologi informasi dan kendala jaringan bisnis (Fitriyani et al., 2020). Disisi lain, UMKM juga menghadapi banyak sekali permasalahan sebelum adanya pandemi COVID-19, yaitu terbatasnya modal kerja,

\section{METODE PELAKSANAAN}

\section{Waktu dan Tempat Kegiatan}

Kegiatan pengabdian pada masyarakat ini dilaksanakan pada bulan September 2020, bertempat di Kantor Kecamatan Bungku Tengah Kabupaten Morowali.

\section{Khalayak Sasaran}

Khalayak sasaran dari program pegabdian pada masyarakat ini adalah pelaku UMKM yang terdampak COVID-19 di Kecamatan Bungku Tengah Kabupaten Morowali.
Sumber Daya Manusia yang rendah, dan minimnya penguasaan ilmu pengetahuan serta teknologi (Sudaryanto \& Hanim, 2002). Kondisi tersebut menambah masalah bagi UMKM, untuk menghadapi situasi pandemi COVID-19 ini tentu dibutuhkan kerjasama yang baik agar semua dapat ditangani dengan maksimal, karenanya diperlukan strategi yang tepat dan dapat mempertahankan UMKM selama dan setelah pandemi COVID-19.

Kondisi UMKM di seluruh Indonesia saat ini mengalami masalah yang sama, termasuk di Kecamatan Bungku Tengah Kabupaten Morowali. Terjadi penurunan penjualan bahkan tidak memiliki pendapatan, namun harus membayar pengeluaran rutin seperti gaji, sewa, cicilan dan bunga bank, dan lain-lain. Berdasarkan hal tersebut, maka tim pengabdian kepada masyarakat Universitas Tadulako, khususnya PSDKU Morowali akan melakukan pengabdian dengan tujuan untuk memberikan sosialisasi tentang mempertahankan UMKM saat pandemi COVID-19.

\section{Metode Pelaksanaan}

Metode pelaksanaan dalam program pengabdian pada masyarakat ini adalah sosialisasi penyampaian materi strategi mempertahankan UMKM yang terdampak COVID-19 di Kecamatan Bungku Tengah Kabupaten Morowali. Jika situasi pandemi COVID-19 berlalu, maka kegiatan akan dilaksanakan secara langsung di tempat kegiatan yang telah ditentukan. 


\section{HASIL dan PEMBAHASAN}

Pengabdian kepada masyarakat yang dilakukan oleh tim pengabdi adalah sosialisasi penyampaian materi strategi

mempertahankan UMKM yang terdampak COVID-19 di Kecamatan Bungku Tengah Kabupaten Morowali.

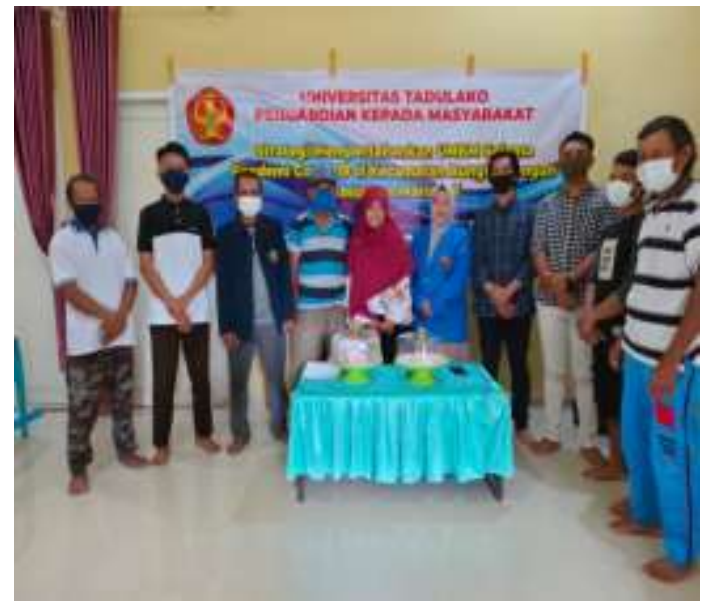

Gambar 1. Pelaku UMKM Terdampak COVID-19 di Kecamatan Bungku Kabupaten Morowli Sumber: Tim Pengabdian Masyarakat

Usaha mikro kecil menengah menentukan kinerja positif bagi pertumbuhan ekonomi nasional. Perananya pada saaat terjadi krisis ekonomi begitu penting tidak terkecuali pada masa pandemic coronavirus disease (COVID-19) yang saat ini masih mengalami peningkatan kasus, tentunya dengan ketentuan yang berbeda. Sedikit berbeda dengan keadaan krisis ekonomi sebelumnya, saat ini UMKM memerlukan waktu yang lebih lama untuk dapat beradaptasi. Setelah beberapa bulan ini berjalan UMKM sudah bias melihat trend an peluang yang ada lalu kemudian melakukan perubahan jenis bisnis mereka, hal inilah salah satu cara mereka akan bisa bertahan. Pemerintah merupakan motor penggerak dengan memberi dukungan penuh bagi pelaku UMKM.

Pemerintah sangat focus kepada pelaku UMKM yang dapat bertahan dan berkembang sehingga mendapatkan dukungan sepenuhnya untuk dapat tumbuh di masa pandemic seperti ini. Adapun indicator UMKM yang berkembang yaitu masih terdapatnya permintaan terhadap produknya dimasyarakat atau meningkatnya jumlah produk yang di pesan konsumen. Kategori UMKM ini akan diberikan program seperti restrukturisasi kredit hingga pemberian Kredit Usaha Rakyat (KUR) dengan subsidi bunga, dan insentif pajak. Namun, bagi UMKM yang tidak sanggup bertahan selama pandemic maka pemerintah sepakat akan memasukkan kelompok tersebut dalam kelompok masyarakat miskin baru dan akan diberi bantuan sosial (bansos) untuk membantu kehidupan sehari-hari pelaku usaha tersebut.

Adapun pertimbangan pemerintah untuk tidak memberikan stimulus dikarenakan akan berpotensi menambah beban pelaku UMKM yang tidak bisa bertahan tersebut, karena jika nantinya diberikan permodalan dari Bank, maka dikhawatirkan akan lebih memberatkan pelaku UMKM ketika ingin bangkit kembali pasca COVID-19. Terdapat 5 
Perencanaan Strategis Mempertahankan Position, Plan, Perspective, Projects, dan UMKM saat Pandemi COVID-19 yaitu Preparedness.

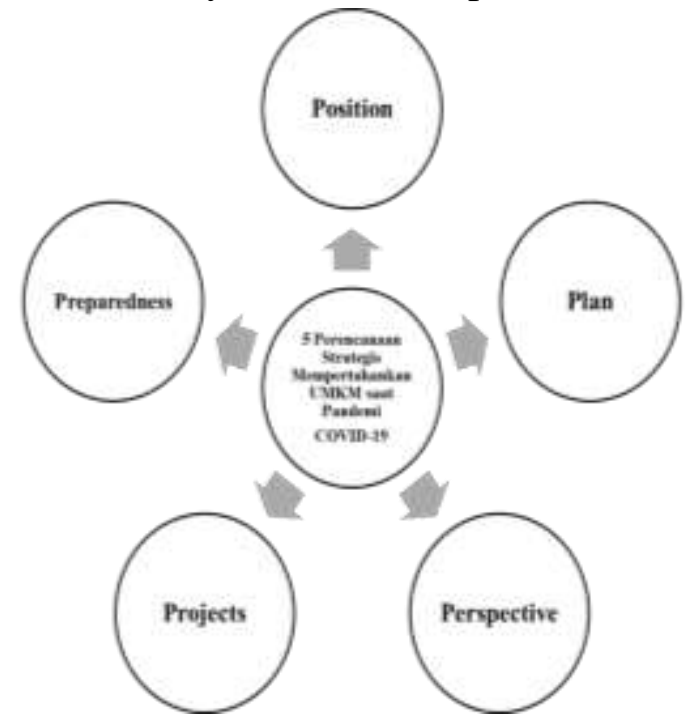

Gambar 2. Stragetegis Mempertahankan UMKM Selama Pandemi Sumber: Tim Pengabdian Masyarakat

Pertanyaan-pertanyaan berikut dapat memandu Anda saat Anda berusaha bangkit kembali dari krisis.

1. Posisi apa yang dapat Anda raih selama dan setelah pandemi?

Untuk membuat keputusan strategis yang cerdas, Anda harus memahami posisi organisasi Anda di lingkungan Anda. Siapa Anda di pasar Anda, peran apa yang Anda mainkan dalam ekosistem Anda, dan siapa pesaing utama Anda? Anda juga harus mengerti ke mana arah Anda. Bisakah Anda mematikan operasi Anda dan membuka kembali tidak berubah setelah pandemi? Bisakah Anda mendapatkan kembali landasan yang hilang? Apakah Anda akan bangkrut, atau dapatkah Anda muncul sebagai pemimpin pasar yang didorong oleh perkembangan selama kuncian?

Kami mendengar banyak perusahaan yang mempertanyakan kelayakan pasca-pandemi mereka, termasuk yang ada di industri perjalanan, rumah sakit, dan perdagangan. Kami juga mendengar perusahaan mempercepat pertumbuhan mereka karena proposisi nilai mereka dalam permintaan tinggi; memiikirkan peralatan kantor untuk rumah, alat komunikasi dan kemampuan kolaborasi internet, dan layanan pengiriman ke rumah. Karena faktor-faktor tersebut, perusahaan akan berbeda dalam ketahanannya. Anda harus mengambil langkah sekarang untuk memetakan posisi Anda saat pandemi mereda.

2. Apa rencana Anda untuk bangkit kembali?

Rencana adalah tindakan yang menunjukkan jalan ke posisi yang ingin Anda capai. Itu harus menjelaskan apa yang perlu Anda lakukan hari ini untuk mencapai tujuan Anda besok. Dalam konteks saat ini, pertanyaannya adalah apa yang harus Anda lakukan untuk melewati krisis dan kembali ke bisnis ketika krisis berakhir. Kurangnya rencana hanya memperburuk disorientasi dalam situasi yang sudah membingungkan. 
Saat menyusun langkah-langkah yang ingin Anda ambil, pikirkan secara luas dan mendalam, dan pandanglah jauh.

3. Bagaimana budaya dan identitas Anda akan berubah?

Perspektif berarti cara organisasi melihat dunia dan dirinya sendiri. Kemungkinan besar, budaya dan identitas Anda akan berubah akibat pandemi. Krisis dapat menyatukan orang-orang dan memfasilitasi semangat ketahanan kolektif - tetapi juga dapat membuat orang terpisah, dengan individu-individu saling tidak percaya satu sama lain dan sebagian besar menjaga diri mereka sendiri. Sangat penting untuk mempertimbangkan bagaimana perspektif Anda dapat berkembang. Seberapa siapkah organisasi Anda secara budaya menghadapi krisis? Apakah situasi yang sedang berlangsung akan menyatukan karyawan Anda atau memisahkan mereka? Apakah mereka akan melihat organisasi secara berbeda ketika ini selesai? Jawaban Anda akan menginformasikan apa yang dapat Anda capai ketika pandemi berakhir.

4. Proyek baru apa yang perlu Anda luncurkan, jalankan, dan koordinasikan?

Jawaban Anda untuk pertanyaan di atas harus mengarahkan Anda ke serangkaian proyek untuk mengatasi masalah terkait virus corona Anda. Tantangannya adalah memprioritaskan dan mengoordinasikan inisiatif yang akan menjadi bukti masa depan organisasi. Waspadalah memulai banyak proyek yang semuanya bergantung pada sumber daya kritis yang sama, yang mungkin individu tertentu, seperti manajer puncak, atau departemen tertentu, seperti TI. Dengan terlalu banyak inisiatif baru, Anda bisa berakhir dengan perang atas sumber daya yang menunda atau menggagalkan respons strategis Anda.

5. Seberapa siap Anda menjalankan rencana dan proyek Anda?

Terakhir, Anda perlu menilai kesiapan organisasi Anda. Apakah Anda siap dan mampu menyelesaikan proyek yang telah Anda uraikan, terutama jika sebagian besar organisasi Anda telah beralih ke pekerjaan jarak jauh? Kami melihat perbedaan besar dalam kesiapsiagaan di tingkat individu, tim, organisasi, dan nasional. Sumber daya yang ada, bersama dengan kecepatan dan kualitas proses pengambilan keputusan, sangat bervariasi, dan perbedaannya akan menentukan siapa yang mencapai dan siapa yang kurang sukses.

Uraian yang dikemukakan merupakan upaya yang dilakukan untuk mempertahankan UMKM selama pandemi COVID-19.

Pandemi COVID-19 memiliki dampak besar pada keberlangsungan bisnis UMKM. Berdasarkan hasil survei, sebanyak $96 \%$ pelaku UMKM mengaku sudah mengalami dampak negatif COVID-19 terhadap proses bisnisnya. Sebanyak $75 \%$ diantaranya mengalami dampak penurunan penjualan yang signifikan. Tidak hanya itu, $51 \%$ pelaku UMKM meyakini kemungkinan besar bisnis yang dijalankan hanya akan bertahan satu bulan hingga tiga bulan ke depan. Sebanyak $67 \%$ pelaku UMKM mengalami ketidakpastian dalam memperoleh akses dana darurat, dan $75 \%$ merasa tidak mengerti bagaimana membuat kebijakan di masa krisis. 
Sementara, hanya $13 \%$ pelaku UMKM yakin bahwa mereka memiliki rencana penanganan krisis dan menemukan solusi untuk mempertahankan bisnis mereka (Caturini, 2020).

Pemerintah lewat Kementerian Koperasi dan UMKM telah berusaha membuka layanan hotline 1500587 sebagai tempat aduan bagi UMKM yang usahanya terkena dampak pandemi COVID-19. Pendataan ini kemudian menjadi acuan pemerintah untuk menyiapkan program antisipasi dampak COVID-19 ini (Caturini, 2020). Terdada 6 langkah mitigasi yang akan dilakukan pemerintah untuk mempertahankan UMKM saat pandemi COVID-19 (Santia, 2020):

1. Memberikan relaksasi cicilan selama 6 bulan untuk UMKM baik melalui KUR maupun juga lewat Lembaga Pengelola Dana Bergulir (LPDB), program mekar, dan lainnya juga sekaligus, bagi koperasi simpan pinjam.

\section{SIMPULAN}

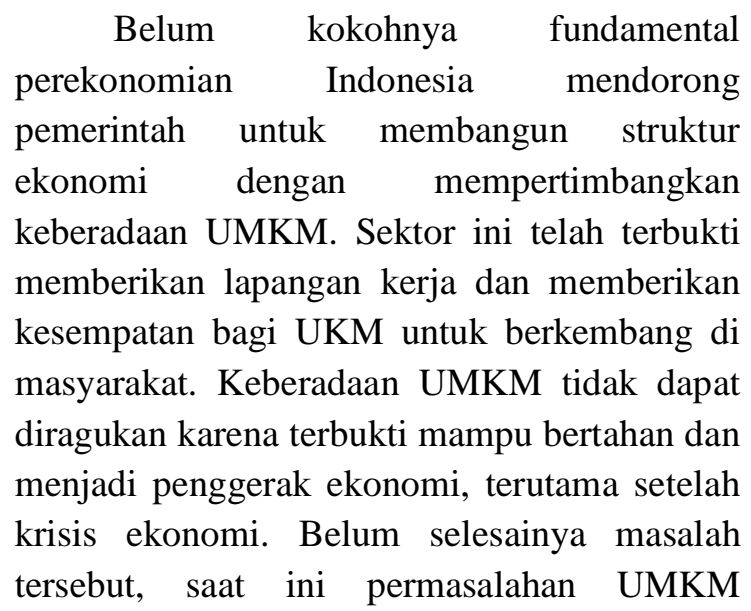

2. Memberikan pinjaman baru untuk ultra mikro pinjamannya yang di bawah Rp. 10.000.000,-

3. Penghapusan pajak kepada UMKM selama 6 bulan.

4. Pemerintah menambah jumlah pnerima bantuan jumlah sosial atau tunai untuk pelaku usaha ultra mikro yang nanti dimasukan dalam jaminan sosial termasuk kartu prakerja, yang merupakan masuk ke dalam program besar pemerintah.

5. Mengintegrasikan program jaminan sosial terutaman kartu sembako murah dengan warung-warung sembako, dengan dana yang digelontorkan melalui jaminan sosial ditujukan untuk meningkatkan daya beli masyarakat dan bisa menggerakan warungwarung tradisional.

6. Mengalokasikan anggaran untuk perkuat daya beli produk UMKM yang beli secara online. semakin memburuk karena dilanda pandemi COVID-19. Berdasarkan hal tersebut, maka hasil pengabdian ini diharapkan dapat memberikan manfaat kepada UMKM di Kecamatan Bungku Tengah Kabupaten Morowali, karena berkontribusi dalam memberikan pemahaman kepada pelaku UMKM untuk bertahan dan bangkit dari krisis dengan melakukan perencanaan strategi yang meliputi position, plan, perspective, projects, and preparedness. 


\section{DAFTAR PUSTAKA}

Caturini, R. (2020, April 11). Ini strategi bertahan bagi pelaku UKM di tengah penjualan tertekan corona. kontan.co.id.

http://industri.kontan.co.id/news/inistrategi-bertahan-bagi-pelaku-ukmdi-tengah-penjualan-tertekan-corona

Fitriyani, I., Sudiyarti, N., \& Fietroh, M. N. (2020). Strategi Manajemen Bisnis Pasca Pandemi Covid-19. Indonesian Journal of Social Sciences and Humanities, 1(2), 8795.

Huba. (2020, April 9). STRATEGI BERTAHAN USAHA MIKRO, KECIL, DAN MENENGAH (UMKM) DITENGAH PANDEMI. Pasundan Ekspres. https://www.pasundanekspres.co/opi ni/strategi-bertahan-usaha-mikrokecil-dan-menengah-umkmditengah-pandemi/

Kompasiana.com. (2020, April 6). Tugas Matakuliah Prof Dr Apollo (Daito). KOMPASIANA.

https://www.kompasiana.com/lotusbi ru2/5e8b560f097f36082c7773a4/asi metri-informasi-covid-19-dan-

keberlanjutan-bisnis

Lund Pedersen, C., \& Ritter, T. (2020). Preparing Your Business for a Postpandemic World. Harvard Business Review Digital Articles.

Narayandas, D., Hebbar, V., \& Li, L. (2020, June 5). Lessons from Chinese Companies' Response to Covid-19. Harvard Business Review. https://hbr.org/2020/06/lessons-fromchinese-companies-response-tocovid-19

Santia, T. (2020, April 15). 6 Strategi Menteri Teten Selamatkan UMKM dari Serangan Corona. liputan6.com. https://www.liputan6.com/bisnis/read /4228375/6-strategi-menteri-tetenselamatkan-umkm-dari-serangancorona

Sudaryanto, S., \& Hanim, A. (2002). Evaluasi kesiapan UKM menyongsong pasar bebas ASEAN (AFTA): Analisis perspektif dan tinjauan teoritis. Jurnal Ekonomi Akuntansi Manajemen, 1(2). 